\title{
KONTRIBUSI PENGUASAAN ALAT PRAKTEK DAN MINAT BELAJAR SISWA TERHADAP HASIL BELAJAR PREKTEK KONSTRUKSI KAYU SISWA KELAS XI PROGRAM KEAHLIAN TEKNIK KONSTRUKSI KAYU SMK NEGERI 1 LUBUK PAKAM
}

\author{
Yafri Riandi Nasution1, Zainuddin² \\ ${ }^{1}$ Alumni Program Studi Pendidikan Teknik Bangunan, Fakultas Teknik UNIMED \\ ${ }^{2}$ Dosen Pengajar Jurusan Pendidikan Teknik Bangunan, Fakultas Teknik UNIMED \\ (Zain_djaros@yahoo.com)
}

\begin{abstract}
ABSTRAK
Penelitian ini bertujuan untuk mengetahui Kontribusi Penguasaan Alat Praktek dan Minat Belajar Siswa Terhadap Hasil Belajar Prektek Konstruksi Kayu Siswa Kelas XI Program Keahlian Teknik Konstruksi Kayu SMK Negeri 1 Lubuk Pakam dengan jumlah responden 30 orang Data penelitian variabel Penguasaan Alat Praktek $\left(X_{1}\right)$ dijaring dengan tes.Minat Belajar $\left(X_{2}\right)$ dijaring dengan angket.Dan Hasil Belajar Praktek Konstruksi kayu(Y) dijaring dengan observasi.

Berdasarkan uji coba instrument didapat hasil : (1) variabel Penguasaan Alat Praktek $\left(\mathrm{X}_{1}\right) 26$ soal yang valid, reliabilitas yang sangat tinggi sebesar 0,80 pada taraf signifikasi $5 \%$. (2) variabel Minat Belajar $\left(\mathrm{X}_{2}\right) 24$ soal yang valid, reliablitas sangat tinggi sebesar 0,84 pada taraf signifikasi $5 \%$.

Berdasarkan pengujian hipotesis dapat disimpulkan: 1) Terdapat Kontribusi yang positif dan berarti antara Penguasaan Alat Praktek terhadap Hasil Belajar Praktek Konstruksi Kayu dengan besar korelasi $\mathrm{rx}_{1} \mathrm{y}=0,770>\mathrm{r}_{\text {tabel }}=0,361$ dan $\mathrm{t}_{\text {hitung }}=6,383>\mathrm{t}_{\text {tabel }}=1,701$ dan dari korelasi parsial diperoleh $\mathrm{rx}_{1} \mathrm{y} \cdot \mathrm{x}_{2}=0,394>\mathrm{r}_{\text {tabel }}=0,361$ dan $\mathrm{t}_{\text {hitung }}=2,466>\mathrm{t}_{\text {tabel }}=1,701$. 2) Terdapat Kontribusi yang positif dan berarti antara Minat Belajar terhadap Hasil Belajar Praktek Konstrukai Kayu dengan besar korelasi $\mathrm{rx}_{2} \mathrm{y}=0,528>\mathrm{r}_{\text {tabel }}=0,361$ dan $\mathrm{t}_{\text {hitung }}=5,292>\mathrm{t}_{\text {tabel }}=1,701$ dan dari korelasi parsial diperoleh $\mathrm{rx}_{2} \mathrm{y} \cdot \mathrm{x}_{1}=$ $0,383>r_{\text {tabel }}=0,361$ dan $t_{\text {hitung }}=2,152>t_{\text {tabel }}=1,699$. 3) Terdapat Kontribusi yang positif dan berarti antara Penguasaan Alat Praktek dan Minat Belajar terhadap Hasil Belajar Praktek Konstruksi Kayu dengan besar korelasi ganda diperoleh $R_{x y(1.2)}=0,879>r_{\text {tabel }}=0,361$ dan uji keberartian korelasi dengan menggunakan Uji-F diperoleh $F_{\text {hitung }}=47,672>F_{\text {tabel }}=3,340$. Dengan demikian Penguasaan Alat Praktek dan Minat Belajar mempunyai Kontribusi yang positif dan berarti terhadap Hasil Belajar Praktek Konstruksi Kayu.

Hasil perhitungan sumbangan relativ dan sumbangan efektif didapat hasil : (1) Sumbangan relatif $X_{1}$ $=78,522 \%$, sumbangan efektif $X_{1}=51,196 \%$. (2) Sumbangan relatif $X_{2}=21,477 \%$, sumbangan efektif $=14,00 \%$. (3) sumbangan efektif $X_{1}$ dan $X_{2}$ terhadap $Y=51,196 \%+14,00 \%=65,196 \%$. Jadi, Sumbangan atau Kontribusi yang diberikan oleh Penguasaan Alat Praktek dan Minat Belajar Terhadap Hasil Belajar Praktek Konstruksi Kayu adalah sebesar 65,196 \%.
\end{abstract}

Kata Kunci : Hasil Belajar Praktek Konstruksi Kayu, Minat Belajar, Penguasaan Alat Praktek

\begin{abstract}
This study aims to determine Contributions Mastery Tools Practice and Interest in Learning Students Against prektek Learning Outcomes Student Class XI Wood Construction Engineering Program Construction Wood SMK Negeri 1 Lubukpakam by the number of respondents 30 peopleThe research data variables Tool Control Practice (X1) enmeshed with tes.Minat Learning (X2) enmeshed with angket.Dan wood Construction Practice Learning Outcomes $(Y)$ captured by observation.Based on the results obtained testing instrument: (1) variable Mastery Training Equipment (X1) 26 questions were valid, reliability was very high at 0.80 at the 5\% significance level. (2) variable Interest in Learning (X2) 24 valid questions, reliablitas very high by 0.84 at the $5 \%$ significance level.Based on hypothesis testing can be concluded: 1) There is a positive and significant contribution of Mastery Tools Learning Outcomes Practice of Practice on Construction Wood with large correlation rxiy $=0.770>$ rtabel $=0.361$ and $t=6.383>$ table $=1.701$ and of partial correlation was obtained
\end{abstract}


$r \times 1 y . x 2=0.394>$ rtabel $=0.361$ and $t=2.466>$ table $=1.701 .2)$ There is a positive and significant contribution of Interest in Learning the Practice Learning Outcomes Konstrukai Wood with large correlation $r x 2 y=0.528>$ rtabel $=0.361$ and $t=5.292>$ table $=1.701$ and $r \times 2 y . x 1$ obtained from the partial correlation $=0.383>$ rtabel $=$ 0.361 and $t=2.152>$ table $=1.699$. 3) There Contributions positive and meaningful between Mastery Tools Practice and Interest in Learning to Learning Outcomes Practice Construction Wood with large double correlation obtained $r x y(1.2)=0,879>$ rtabel $=0.361$ and test the significance of correlation using the Test- $F$ was obtained of $F=47.672>$ Ftabel $=3.340$. Thus Mastery Tools Practice and Interest in Learning has a positive and significant contribution to the Learning Outcomes Practice Construction Wood. The results of the calculations and the relative contribution of the effective contribution of the results obtained: (1) the relative contribution of $X 1=78.522 \%$, the effective contribution of $X 1=51.196 \%$. (2) the relative contribution of $X 2=$ $21.477 \%$, the effective contribution $=14.00 \%$. (3) the effective contribution of X1 and X2 to $Y=51.196 \%+$ $14.00 \%=65.196 \%$. Thus, donations or contributions that the mastery of Practice and Interest in Learning Tool Learning Outcomes Practice Against Wood Construction amounted to 65.196\%.

Keywords: Interest in Learning, Learning Outcomes Practice Construction Wood, Mastery Practice Tools

\section{Pendahuluan}

Proses pendidikan di sekolah selalu mengalami suatu penyempurnaan yang pada akhirnya menghasilkan suatu produk atau hasil pendidikan yang berkualitas. Berbagai usaha telah dilakukan oleh pengelola pendidikan untuk meningkatkan prestasi belajar siswa.Langkah ini merupakan langkah awal untuk meningkatkan kualitas Sumber Daya Manusia (SDM).Seiring dengan perkembangan zaman penyediaan sumber daya manusia yang berkualitas sangat diperlukan. SMK Negeri 1 Lubuk Pakam bidang keahlian Teknik Konstruksi Kayu merupakan salah satu lembaga pendidikan formal yang memberikan bekal berupa ilmu pengetahuan, keterampilan, sikap, etos kerja dan pengetahuan teknologi yang bertujuan menciptakan lulusan-lulusan yang siap pakai dalam dunia kerja. Tujuan pendidikan di SMK Negeri 1 Lubuk Pakam adalah memberikan pengetahuan dan keterampilan, sehingga menghasilkan tamatan yang dapat bekerja di dunia industri dan dunia usaha nasional maupun internasional dengan dasar keimanan dan ketaqwaan melalui : (1) menyiapkan peserta didik dengan ilmu pengetahuan dan teknologi, seni budaya dan karakter bangsa agar mampu mengembangkan diri sesuai dengan kompetensi keahlian masing-masing,(2) menyiapkan peserta didik yang memililiki daya kompetitif dan adaptif di lingkungan kerja maupun berwirausaha, (3) membekali peserta didik dengan kompetensi keahlian melalui sertifikasi yang bertaraf nasional maupun internasional, (4) menyiapkan tamatan yang siap bekerja dan berwirausaha dengan daya kompetitif dan memiliki keunggulan.

Berdasarkan hasil observasi dan wawancara yang dilakukan peneliti di SMK Negeri 1 Lubuk Pakam, dikemukakan bahwa nilai mata pelajaran konstruksi bangunan belum mencapai kriteria ketuntasan minimum (KKM). Diketahui pada tahun pelajaran 2015/2016 dengan jumlah siswa 15 orang, yang memperoleh nilai $<70$ kategori tidak kompeten sebanyak 13,33\%,cukup kompeten sebanyak $53,33 \%$, kategori kompeten sebanyak 20,00\% dan kategori sangat kompeten sebanyak $13,33 \%$.

Rendahnya hasil belajar yang dialami oleh siswa dapat disebabkan oleh banyak faktor. Menurut Daryanto (2010) faktor-faktor yang dapat mempengaruhi belajar siswa dapat dibedakan menjadi 3 (tiga) macam, yaitu: (1)faktor Internal (faktor dari dalam diri siswa), yakni keadaan/kondisi jasmani dan rohani siswa, (2) faktor Eksternal (faktor dari luar diri siswa), yakni kondisi lingkungan di sekitar diri siswa, (3) faktor pendekatan belajar (approach to learning), yakni jenis upaya belajar siswa yang meliputi strategi dan model yang digunakan siswa untuk melakukan kegiatan pembelajaran materi-materi pelajaran. Sehingga sebagian besar hasil belajar siswa tidak mencapai nilai batas ketuntasan belajar yang ditetapkan.Hal ini bukan berarti siswa tidak memiliki kemampuan dalam Praktek Konstruksi Kayu, tetapi masih banyak unsur yang terkait dengannya

Praktek konstruksi kayu adalah mata diklat keterampilan produktif yang menghasilkan dan membekali siswa dengan pengetahuan dan sikap yang nantinya 


\section{Kontribusi Penguasaan Alat Praktek dan Minat Belajar Siswa Terhadap Hasil Belajar Prektek Konstruksi Kayu Siswa Kelas XI Program Keahlian Teknik Konstruksi Kayu SMK Negeri 1 Lubuk Pakam}

membuat siswa dapat mandiri dan siap pakai dalam dunia industri.Praktek konstruksi kayu adalah sebagai dasar siswa dalam mempelajari dan mampu menguasai alat praktek, membuat sambungan kayu, membuat komponen kayu, serta merangkai komponen - komponen kayu tersebut menjadi suatu konstruksi kayu yang utuh.

Untuk dapat menguasai praktek kontruksi kayu maka siswa harus menguasai alat praktek.Alat praktek adalah sesuatu yang membantu meringankan suatu pekerjaan dalam kegiatan praktek. Dalam hal ini alat praktek yang digunakan adalah alat kerja manual ata alat kerja tangan yang tidak menggunakan mesin,diantaranya alat - alat yang digunakan ialah ; gergaji, ketam, pahat, siku, meteran, palu, pensil, karaspen, kikir kayu dan klem.

Disamping itu fakta yang menunjang hasil belajar praktek konstruksi kayu yaitu faktor internal saja seperti minat, bakat dan motivasi.Dalam penelitian ini yang dikaji dari segi minat belajar.Slameto (2003:180) menyatakan: "Minat adalah suatu rasa lebih suka dan rasa keterikatan pada suatu hal atau aktivitas, tanpa ada yang menyuruh". Hal ini tentunya akan menentukan seberapa besar prestasi yang dicapai oleh siswa itu sendiri, semakin besar minatnya maka prestasi yang ingin dicapai juga akan lebih mudah didapat. Selanjutnya Dalyono (1997) berpendapat bahwa "Minat yang besar terhadap sesuatu merupakan modal yang besar artinya untuk mencapai tujuan yang diminati".

\section{Kajian Teori}

Hasil belajar merupakan bagian terpenting dalam pembelajaran. Nana Sudjana (2009 : 3)"mendefinisikan hasil belajar siswa pada hakikatnya adalah perubahan tingkah laku sebagai hasil belajar dalam pengertian yang lebih luas mencakup bidang kognitif, efektif, dan psikomotorik". Dimyati dan Mudjiono (2006 : 3-4)'hasil belajar merupakan hasil dari suatu interaksi tindak belajar dan tindak mengajar. Dari sisi guru, tindak mengajar diakhiri dengan proses evaluasi hasil beajar. Dari sisi siswa, hasil belajar merupakan berakhirnya pengajaran dari puncak proses belajar".

Penguasaan dalam kamus besar Bahasa Indonesia (1991 : 213) diartikan sebagai pemahaman atau kesanggupan untuk menggunakan pengetahuan, kepandaian dan sebagainya. Berdasarkan pengertian tersebut data dinyatakan bahwa penguasaan adalah pemahaman. Pemahaman bukan saja berarti mengetahui yang sifatnya mengingat (hafalan) saja, tetapi mampu mengungkapkan kembali dalam bentuk lain atau dengan kata - kata sendiri sehingga mudah dimengerti makna bahan yang dipelajari, tetapi tidak mengubah arti yang didalamnya.

Secara rinci Fernandes (2000) menjelaskan bahwa " penguasaan terdiri dari beberapa aspek yaitu : pengetahuan, pemahaman, analisa, sintesis, dan evaluasi". Penguasaan dapat ditunjukaan melalui hasil belajar, dengan kata lain penguasaan adalah cerminan keberhasilan siswa dalam proses belajar. Belajar adalah suatu usaha dengan sadar dan sengaja dilakukan untuk mendapatkan suatu tngkah laku atau keterampilan baru. Ciri-ciri perubahan tingkah laku dalam pengertian belajar menurut Sujono (1984) adalah : 1) Perubahan yang terjadi secara sadar, 2) Perubahan dalam belajar bersidat kontiniu fungsional, 3) Perubahan dalam belajar bersifat pasif menjadi aktif, 4) Perubahan dalam belajar bersifat terarah, 5) Perubahan dalam belajar mencakup aspek tingkah laku yang positif, 6) Perubahan dalam belajar bukan bersifat sementara.

Dengan adanya minat, merupakan salah satu sumber rasa tertarik seseorang akan sesuatu hal, sehingga mendorong seseorang untuk melaksanakan apa yang diinginkan, memberi arah secara umum kemana seseorang akan bertindak agar dapat kepuasan dan kenikmatan dalam hidupnya. Jadi minat timbul karna individu memerlukan suatu objek yang menarik dan cenderung untuk melakukan aktivias tersebut tanpa harus dibebani. Selanjutnya Slameto (2003:180) menyimpulkan bahwa : "Minat adalah suatu rasa lebih suka dan rasa ketertarikan pada suatu hal atau aktivitas, tanpa ada yang menyuruh". Minat pada dasarnya penerimaan suatu hubungan antara diri sendiri dengan sesuatu diluar diri. Iskandar (2001:9) mengatakan: “ Minat adalah usaha dan kemauan untuk mempelajari (learning) dan mencari sesuatu". Berdasarkan beberapa pendapat diatas, dapat disimpulkan bahwa minat seorang siswa terhadap suatu objek dapat dipengaruhi dengan adanya penetahuan akan manfaat objek tersebut dan 
pengaruh faktor lain pada individu, situasi dan lingkungannya.

Suatu minat dapat diekspresikan melalui suatu pernyataan yang menunjukkan bahwa siswa lebih menyukai suatu hal dari pada hal lainnya, dapatpula dimanifestasikan melalui partisipasi dalam suatu aktivitas. Siswa yang memiliki minat pada subjek tertentu cenderung memberikan perhatian pada subjek tersebut.

Penguasaan dengan suatu bidang adalah kemampuan unrtuk menyelesaikan atau mengusai suatu bidang akan berusaha mencari atau menambah ilmu pengetahuan yang berhubungan dengan bidang tersebut.. Penguasaan menunjuk kepada hasil usaha yang dicapai seseorang melalui perbuatan belajar. Hal ini dapat diartikan semakin baik penguasaan siswa dibidang tersebuat akan membantu siswa dalam meningkatkan hasil belajar prakteknya. Salah satu bidang tersebut adalah alat yang merupakan faktor pendukung untuk meningkatkan hasil belajar praktek konstruksi kayu.

Dalam kegiatan belajar, minat merupakan salah satu faktor psikologi yang memungkinkan terjadinya dorongan dan konsentrasi belajar. Menyadari hal itu maka guru dalam proses belajar harus mempunyai kemampuan tidak hanya membekali diri dengan materi saja tetapi juga harus mengetahui bagaimana menyampaikan pelajaran agar menarik perhatian siswa, sehingga apa yang menjadi tujuan dari pengajaran tersebut dapat dicapai.

Dalam hal ini tentu saja minat yang baik akan memberikan kepada yang baik pula dengan hasil belajar, karena dengan adanya minat akan menimbulkan rasa suka terhadap apa yang dipelajari dan akan senantiasa berusaha untuk dapat menguasai apa yang dikehendaki. Jadi dalam upaya pencapaian hasil belajar yang diperoleh adalah merupakan perpaduan antara minat terhadap pelajaran itu sendiri dan juga faktor-faktor lain yang mendukungnya

\section{Metodologi Penelitian}

Metode penelitian adalah cara yang digunakan oleh peneliti dalam mengumpulkan data penelitiannya. Metode yang digunakan dalam penelitian ini adalah metode deskriptif korelasional yaitu teknik pengumpulan data untuk mendapatkan gambaran tentang hubungan gejala-gejala yang ada pada saat penelitian diadakan. Metode deskriptif merupakan metode dalam meneliti suatu kelompok manusia, suatu objek, suatu kondisi, suatu sistem pendidikan ataupun suatu kelas pada masa sekarang.

Penelitian ini dilaksanakan di kelas XI SMK Negeri 1 Lubuk Pakam Program Studi Keahlian Teknik Konstruksi Kayu pada mata pelajaran Praktek Konstuks Kayu. Penelitian dilaksanakan pada semester ganjil Tahun Ajaran 2016/2017. Menurut pendapat Arikunto (2002 : 108) bahwa populasi adalah keseluruhan subjek penelitian. Adapun yang menjadi populasi dalam penelitian ini adalah seluruh siswa kelas XI Jurusan Teknik Konstruksi Kayu di SMK Negeri 1 Lubuk Pakam Tahun Ajaran 2016/2017 yang berjumlah 30 orang.

Penelitian ini menggunakan dua variabel yaitu variabel bebas $\left(X_{1}\right.$ dan $\left.X_{2}\right)$ dan variabel terikat (Y).Variabel bebas (Variabel Independen) adalah variabel yang mempengaruhi atau yang menjadi sebab perubahannya atau timbulnya variabel terikat (variabel dependen).Sedangkan variabel terikat (dependen) adalah yang mempengaruhi atau yang menjadi akibat, karena adanya variabel bebas. Adapun yang menjadi variabel bebas adalah penguasaan alat praktek $\left(\mathrm{X}_{1}\right)$ dan minat belajar $\left(\mathrm{X}_{2}\right)$, sedangkan variabel terikatnya adalah hasil belajar praktek konstrkusi kayu (Y).

Penguasaan alat praktek diperoleh melalui tes, dengan 4 pilihan jawaban, yaitu 1 pilihan yang benar dan 3 pilihan pengecoh. Penyusunan atau pembuatan soal untuk tes hasil belajar diambil dari materi pelajaran kelas XI program studi teknk konstruksi kayu. Setiap butir soal yang dijawab benar diberi nilai 1 dan untuk jawaban yang salah diberi nilai 0 .

Instrumen minat belajar $\left(\mathrm{X}_{2}\right)$ dijaring dengan menggunakan angket. Instrumen yang disusun oleh peneliti mengacu pada hakekat ubahan dan aspeknya serta beberapa instrumen berdasarkan minat belajar yang telah diuraikan terlebih dahulu, dirumuskan kedalam bentuk defenisi operasional yang kemudian dijabarakan dalam bentuk kisi - kisi dibuat menadi butir - butir soal/item.

Hasil belajar praktek konstruksi kayu dijaring dengan melakukan observasi atau pengamatan langsung saat melakukan praktek membuat sambungan kayu. Adapun pedoman penskornya adalah dengan melihat indikator indikator penilaiannya yang telah dibuat pada format lembar penilaian. 


\section{Kontribusi Penguasaan Alat Praktek dan Minat Belajar Siswa Terhadap Hasil Belajar Prektek Konstruksi Kayu Siswa Kelas XI Program Keahlian Teknik Konstruksi Kayu SMK Negeri 1 Lubuk Pakam}

\section{Hasil dan Pembahasan}

Sebelum digunakan sebagai alat pengumpul data, tes Instrumen tiap variabel tersebut diuji cobakan pada siswa di luar sampel yaitu siswa yang telah mempelajari pokok bahasan dalam instrumen penelitian, serta didiskusikan bersama para ahli statistik terlebih dahulu sehingga dapat diketahui validitas, reliabilitas, tingkat kesukaran, dan daya pembeda tes tersebut. Sedangkan instrumen non tes dalam penelitian ini berupa observasi, harus didiskusikan bersama para ahli sehingga diperoleh validitas isi intrumen nontes tersebut. Uji instrumen dilaksanakan dikelas XI Program Keahlian Teknik Konstruksi Batu Beton SMK Negeri 2 Medan.

Berdasarkan data yang diperoleh melalui tes penguasaan alat peraktek dari hasil penelitian dengan jumlah responden 30 orang terdapat skor tertinggi 28 dan skor yang terendah 10. dengan rata - rata $(M)=19,1$ dan standar deviasi $(\mathrm{SD})=4,7$.

Berdasarkan data variabel Minat Belajar $\left(\mathrm{X}_{2}\right)$ dari hasil penelitian yang diperoleh dengan jumlah responden 30 orang siswa terdapat skor tertinggi 122; skor terendah 69; dengan rata-rata $(\mathrm{M})=94,1$ dan standar deviasi $(\mathrm{SD})=15,9$.

Berdasarkan data variabel Hasil Belajar Praktek Konstruksi Kayu(Y) dari hasil penelitian yang diperoleh dengan jumlah responden 30 orang siswa terdapat skor tertinggi 95; skor terendah 59; dengan rata-rata $(M)=75,6$ dan standar deviasi $(S D)=8,3$.

Berdasarkan

perhitungan

kecenderungan variabel dapat dilihat bahwa jumlah responden yang termasuk kategori skor tinggi sebanyak 9 orang (30\%), kategori cukup sebanyak 15 orang $(50 \%)$, dan kategori kurang sebanyak 6 orang $(20 \%)$. Dengan demikian dapat disimpulkan bahwa Penguasaan Alat Praktek siswa Kelas XI Program Keahlian Teknik Konstruksi Kayu SMK Negeri 1 Lubuk Pakam Tahun Ajaran 2016/2017 termasuk kategori cukup.

Berdasarkan perhitungan kecenderungan variabel dapat dilihat bahwa jumlah responden yang termasuk kategori skor tinggi sebanyak 9 orang $(30 \%)$, kategori cukup sebanyak 14 orang $(46,672 \%)$, dan kategori kurang sebanyak 7 orang $(23,33 \%)$. Dengan demikian dapat disimpulkan bahwa Minat Belajar siswa Kelas XI Program Keahlian Teknik Konstruksi Kayu SMK Negeri 1 Lubuk
Pakam Tahun Ajaran 2016/2017 termasuk kategori cukup.

Berdasarkan perhitungan kecenderungan varaibel dapat dilihat bahwa jumlah responden yang termasuk kategori skor tinggi sebanyak 2 orang $(6,67 \%)$, kategori cukup sebanyak 22 orang $(73,33 \%)$, dan kategori kurang sebanyak 6 orang (20\%). Dengan demikian dapat disimpulkan bahwa Hasil Belajar Praktek Konstruksi Kayu siswa Kelas XI Program Keahlian Teknik Konstruksi Kayu SMK Negeri 1 Lubuk Pakam Tahun Ajaran 2016/2017 termasuk kategori cukup.

Berdasarkan perhitungan uji normalitas dapat dilihat uji normalitas data masingmasing variabel penelitian diperoleh $X^{2}$ hitung < $\chi^{2}$ tabel pada taraf signifikansi $5 \%$. Dengan demikian dapat disimpulkan bahwa data variabel Penguasaan Alat Praktek $\left(\mathrm{X}_{1}\right)$, Minat Belajar $\left(X_{2}\right)$ dan Hasil Belajar Praktek Konstruksi Kayu (Y) adalah berdistribusi normal.

Dari hasil perhitungan korelasi sederhana dengan metode Product Moment pada lampiran 18 diperoleh koefisien korelasi antara $X_{1}$ terhadap $Y=0,770$; sedangkan $r_{\text {tabel }}$ dengan $\mathrm{N}=30$ dan taraf signifikansi $5 \%$ adalah 0,361 . Dengan demikian harga $r_{\text {hitung }}>r_{\text {tabel }}$ $(0,770>0,361)$ sehingga koefisien korelasi variabel $\mathrm{X}_{1}$ terhadap variabel $\mathrm{Y}$ adalah signifikan.

Selanjutnya dilakukan uji keberartian korelasi dengan menggunakan uji-t diperoleh $t_{\text {hitung }}$ sebesar 6,383 . Untuk harga $t_{\text {tabel }}$ dengan $\mathrm{dk}=30-2=28$ adalah 1,701 terlihat $\mathrm{t}_{\text {hitung }}>$ $t_{\text {tabel }}$ yaitu $(6,383>1,701)$. Sesuai dengan kriteria penerimaan dan penolakan hipotesis, maka hipotesis kerja (Ha) yang diajukan diterima pada taraf signifikansi 5\%. Dengan demikian dinyatakan terdapat Kontribusi yang berarti antara Penguasaan Alat Praktek $\left(X_{1}\right)$ terhadap Hasil Belajar Praktek Konstruksi Kayu (Y).

Dari hasil perhitungan korelasi sederhana dengan metode Product Moment pada lampiran 19 diperoleh koefisien korelasi antara $\mathrm{X}_{2}$ terhadap $\mathrm{Y}=0,528$; sedangkan $\mathrm{r}_{\text {tabel }}$ dengan $N=30$ dan taraf signifikansi 5\% adalah 0,361 . Dengan demikian harga $r_{\text {hitung }}>r_{\text {tabel }}$ $(0,528>0,361)$ sehingga koefisien korelasi variabel $\mathrm{X}_{2}$ terhadap variabel $\mathrm{Y}$ adalah signifikan.

Selanjutnya dilakukan uji keberartian korelasi dengan menggunakan uji-t diperoleh 
$t_{\text {hitung }}$ sebesar 5,292. Untuk harga $t_{\text {tabel }}$ dengan $\mathrm{dk}=30-2=28$ adalah 1,701 terlihat $\mathrm{t}_{\text {hitung }}>$ $t_{\text {tabel }}$ yaitu $(5,292>1,701)$. Sesuai dengan kriteria penerimaan dan penolakan hipotesis, maka hipotesis kerja (Ha) yang diajukan diterima pada taraf signifikansi 5\%. Dengan demikian dinyatakan terdapat Hubungan yang berarti antara Minat Belajar $\left(X_{2}\right)$ terhadap Hasil Belajar Praktek Konstruksi Kayu (Y).

Dari perhitungan korelasi ganda pada lampiran 22 diperoleh koefisien korelasi antara $\mathrm{X}_{1}$ dan $\mathrm{X}_{2}$ terhadap $\mathrm{Y}$ yaitu $\mathrm{R}_{\mathrm{Y}(1,2)}=$ 0,879 ; sedangkan $r_{\text {tabel }}$ dengan $N=30$ pada taraf signifikansi $5 \%$ sebesar 0,355 . Dengan demikian harga $R_{x y(1.2)}>r_{\text {tabel }}(0,808>0,361)$, maka dapat dikatakan terdapat Hubungan yang signifikan antara variabel $X_{1}$ dan $X_{2}$ terhadap variabel $Y$.

Selanjutnya dilakukan uji keberartian korelasi ganda dengan menggunakan uji-F diperoleh $F_{\text {hitung }}=47,672$. Dengan dk pembilang $=2$ (banyak variabel bebas) dan $\mathrm{dk}$ penyebut $=$ $\mathrm{N}-\mathrm{k}-1=30-2-1=27$, pada taraf signifikansi 5\% diperoleh $\mathrm{F}_{\text {tabel }}=3,354$ terlihat bahwa $F_{\text {hitung }}>F_{\text {tabel }}(47,672>3,354)$.

Dari hasil perhitungan di atas, dapat disimpulkan bahwa hipotesis penelitian yang diajukan menyatakan terdapat Kontribusi yang positif dan berarti secara bersama-sama antara Penguasaan Alat Praktek dan Minat Belajar terhadap Hasil Belajar Praktek Konstruksi Kayu dapat diterima dan teruji kebenarannya. Besarnya Kontribusi Penguasaan Alat Praktek $\left(X_{1}\right)$ dan Minat Belajar $\left(X_{2}\right)$ terhadap Hasil Belajar Praktek Konstruksi Kayu (Y) yaitu; 65,196\%.

Dari perhitungan sumbangan efektif dan sumbangan relative kontribusi variabel Penguasaan Alat Praktek dan Minat Belajar terhadap Hasil Belajar Praktek Konstruksi Kayu $\left(\mathrm{SE}_{1.2}=65,196\right)$. Dengan demikian Kontribusi Penguasaan Alat Praktek dan Minat Belajar terhadap Hasil Belajar Praktek Konstruksi Kayu sebesar 65,196\%.

\section{Kesimpulan dan saran}

\subsection{Kesimpulan}

Berdasarkan hasil penelitian yang diuraikan pada Bab IV, maka dapat disimpulkan bahwa:

1) Terdapat Kontribusi yang positif dan berarti antara Penguasaan Alat Praktek terhadap Hasil Belajar Praktek Konstruksi Kayu pada siswa kelas XI
Program Keahlian Teknik Konstruksi Kayu SMK Negeri 1 Lubuk Pakam Tahun Ajaran 2016/2017. Hal ini dibuktikan dengan hasil perhitungan korelasi antar variabel dengan korelasi sederhana $\left(\mathrm{rX}_{1} \mathrm{y}\right)=0,770>\mathrm{r}_{\text {tabel }}$ dengan $\mathrm{N}=30$ dan taraf signifikansi 5\% adalah 0,361 dan uji keberartian diperoleh $t_{\text {hitung }}>t_{\text {tabel }}(6,383>1,701)$. Selanjutnya perhitungan korelasi parsial diperoleh koefisien korelasi parsial $\left(\mathrm{rX}_{1} \mathrm{y} . \mathrm{X}_{2}\right)=$ $0,394>r_{\text {tabel }}$ dengan $\mathrm{N}=30$ dan taraf signifikansi 5\% adalah 0,361 dan uji keberartian korelasi parsial diperoleh $t_{\text {hitung }}>t_{\text {tabel }}(2,466>1,701)$.

2) Terdapat Kontribusi yang positif dan berarti antara Minat Belajar terhadap Hasil Belajar Praktek Konstruksi Kayu pada siswa kelas XI Program Keahlian Teknik Konstruksi Kayu SMK Negeri 1 Lubuk Pakam Tahun Ajaran 2016/2017. Hal ini dibuktikan dengan hasil perhitungan korelasi antar variabel dengan korelasi sederhana $\left(\mathrm{rX}_{2} \mathrm{y}\right)=$ $0,528>r_{\text {tabel }}$ dengan $\mathrm{N}=30$ dan taraf signifikansi $5 \%$ adalah 0,361 dan uji keberartian diperoleh $t_{\text {hitung }}>t_{\text {tabel }}$ $(5,292>1,701)$. Selanjutnya perhitungan korelasi parsial diperoleh koefisien korelasi parsial $\left(\mathrm{rX}_{2 \mathrm{y}} \mathrm{y} \cdot \mathrm{X}_{1}\right)=0,383>\mathrm{r}_{\text {tabel }}$ dengan $\mathrm{N}=30$ dan taraf signifikansi $5 \%$ adalah 0,361 dan uji keberartian korelasi parsial diperoleh $t_{\text {hitung }}>t_{\text {tabel }}$ $(2,152>1.699)$.

3) Terdapat Kontribusi yang positif dan berarti secara bersama-sama antara Penguasaan Alat Praktek dan Minat Belajar terhadap Hasil Belajar Praktek Konstruksi Kayu pada siswa kelas XI Program Keahlian Teknik Konstruksi Kayu SMK Negeri 1 Lubuk Pakam Tahun Ajaran 2016/2017. Hal ini dibuktikan dengan hasil perhitungan korelasi ganda $\left(R_{x_{y}} 1.2\right)=0.879>r_{\text {tabel }}$ dengan $N=30$ dan taraf signifikansi $5 \%$ adalah 0,355 dan uji keberartian korelasi ganda diperoleh $t_{\text {hitung }}>t_{\text {tabel }}$ $(47,672>3,340)$. 


\section{Kontribusi Penguasaan Alat Praktek dan Minat Belajar Siswa Terhadap Hasil Belajar Prektek Konstruksi Kayu Siswa Kelas XI Program Keahlian Teknik Konstruksi Kayu SMK Negeri 1 Lubuk Pakam}

4) Terdapat Kontribusi yang efektif secara bersama-sama antara Penguasaan Alat Praktek dan Minat Belajar terhadap Hasil Belajar Praktek Kontruksi Kayu pada siswa kelas XI Program Keahlian Teknik Kontsruksi Kayu SMK Negeri 1 Lubuk Pakam Tahun Ajaran 2016/2017. Hal ini dibuktikan dengan hasil perhitungan sumbangan efektif yang memberikan hasil $\mathrm{SE}_{1.2}=65,196 \%$.

Setelah melihat hasil penelitian, pembahasan dan kesimpulan maka peneliti memberikan impilkasi sebagai berikut :

1) Dengan diterimanya hipotesis pertama maka perlu kiranya menjadi pertimbangan kepada guru untuk memperbaiki penguasaan penggunaan alat kerja praktek kayu siswa yang dapat mempengaruhi hasil belajar praktek konstruksi kayu. Strategi yang dapat dilakukan guru dalam memperbaiki penguasaan alat praktek adalah terlebih dahulu mengajarkan siswa materi dan praktek langsung mengenai peralatan - peralatan apa saja yang akan mereka gunakan sebelum kerja yang mereka gunakan saat praktek konstruksi kayu.

2) Dengan diterimanya hipotesis kedua maka perlu kiranya menjadi pertimbangan kepada guru dalam upaya meningkatkan upaya minat belajar yang dapat mendukung hasil belajar praktek konstruksi kayu. Upaya yang dapat dilakukan untuk

3) Dengan diterimanya hipotesis ketiga maka guru lebih memperhatikan siswa dan mengasah kemampuan mereka dalam menggunakan alat praktek kayu sehingga siswa lebih merasa percaya diri dalam mengasilkan hasil praktek yang lebih baik lagi dan meningkatkan hasil belajar siswa serta mengetahui minat belajar siswa sehingga dapat mempengaruhi kemampuan mereka dalam belajar

\subsection{Saran}

Berdasarkan kesimpulan di atas saran yang dapat diberikan peneliti untuk adalah :

1. Untuk memperbaiki penguasaan alat praktek siswa maka guru sebagai pendidik memberikan latihan yang dapat menambah kemampuan psikomotor siswa dalam menggunakan alat kerja praktek kayu saat praktek.

2. Untuk meningkatkan minat belajar diharapkan guru sebagai pendidik lebih memperhatikan siswa dan memberikan dorongan - dorongan yang positif kepada siswa dan lebih menghargai siswa.

3. Untuk meningkatkan hasil belajar praktek konstruksi kayu, diharapkan guru melakukan upaya yang dapat membantu siswa dalam dalam untuk menguasai alat praktek kayu dan meningkatkan minat belajar.

\section{Daftar Pustaka}

Arifin. 1987. Kapita Selekta Pendidikan. Jakarta: Bumi Aksara

Arijo. 2001. Pedoman Belajar. Jakarta : Balai Pustaka

Arikunto, Suharsimi 1995. Dasar - Dasar Evaluasi Pendidikan. Yogyakarta: Bumi Aksara.

Arikunto, Suharsimi 1998. Prosedur Penelitian suatu Pendekatan Praktik. Jakarta: Rineka Cipta.

Arikunto, Suharsimi. 2002. Dasar - Dasar Evaluasi Hasil Belajar. Jakarta: Bina Aksara.

Arikunto, Suharsimi. 2006. Prosedur Penelitian suatu Pendekatan Praktik (edisi revisi VI). Jakarta : Rineka Cipta. 2010. Prosedur Penelitian suatu Pendekatan Praktik. Jakarta : Rineka Cipta.

Baharuddin (2007). Teori Belajar dan Pembelajaran. Yogyakarta : Ar-Ruzz Media

Daryanto.(2010). Keterampilan Kejuruan Konstruksi Kayu. Bandung: Satu Nusa Studio.

Dalyono. 1997. Belajar dan Pembelajaran. Jakarta: Rineka Cipta

Daryanto. 2010. Undang-undang Dasar Negara Republik Indonesia No. 20 tahun 2003 Tentang Sistem Pendidikan Nasional, Jakarta: Depdikbud.

Dimyati dan Mudjiono.(2006). Belajar dan Pembelajaran. Jakarta: Rineka Cipta 
Effendi 1994. Makalah Seminar Bimbingan dan Konseling. Bandung : UPI

Fernandez, H.J.K. 1984. Evaluation of Educational Programes. Jakarta : BP3K

Gitasudarmo dan Mudjiono. 2006. Perilaku Belajar. Yogyakarta: Erlangga

Hamalik, Oemar. 1990. Evaluasi Kurikulum. Bandung: PT. Remaja Rosdakarya

Kamus Besar Bahasa Indonesia. 1991. Jakarta : Balai Pustaka

Kartono, 1992. Strategi Pembelajaran; Berorientasi Standar Proses Pendidikan. Jakarta : Kencana Prenada Media Group

Landgren, Clay Hendry. 1980. Education Psychology In The Classroom. New York: Edition 6.

Pidarta, Sumadi. 1997. Psikologi Pendidikan. Bandung: Yayasan Pendidikan Guru Jawa Barat.

Poerwardarminta. 1994. Kamus Umum Bahasa Indonesia. Jakarta: Balai Pustaka.

Ramayulis.1998. Ilmu Pendidikan Islam. Jakarta : Kalam Mulia.

Rifa'i, Mien.A. 2004. Kamus biologi/penyusun akhir cetakan ke-4, Jakarta Balai Pustaka

Slameto. 2003. Belajar dan Faktor-faktor Yang Mempengaruhinya. Jakarta: Rineka Cipta.

Sudjana. 1992. Metode Statistik. Bandung : Tarsito

Sudjana. 1997. Penilaian hasil Proses Belajar Mengajar. Bandung: PT. Remaja RosdaKarya.

Sudjana. 1997. Penilaian hasil Proses Belajar Mengajar. Bandung: PT.Tarsito.

Sudjana. 2005. Metode Statistik. Bandung : Tarsito

Sudjana, Nana. 2009. Penilaian hasil Proses Belajar Mengajar. Bandung: PT. Remaja RosdaKarya.

Sujono.1998. Pendekatan Kualitatif . Jakarta: LPSP3.

Sukardi. 1998. Metodologi Penelitian Pendidikan. Jakarta : PT. Bumi Aksara

Surachmadi, A.M.1993. Motivasi Belajar Mengajar. Jakarta: Raja Gravindo Persada

Suryabrata. 2002.Psikologi Pendidikan. Jakarta: PT. Grafindo Perkasa Rajawali.

Usman, Moh. Uzer. 1994. Menjadi Guru Profesional. Bandung : PT. Remaja Rosada
Winataputra, Udin, S.2007. Teori Belajar dan Pembelajaran. Jakarta : Universitas Terbuka

Winkel, WS.1994. Psikologi Pengajaran. Yogyakarta: Fakultas Psikologi UGM 